\title{
MANAJEMEN PENGEMBANAGAN TENAGA PENDIDIK DI SMA PRIMAGANDA BULUREJO DIWEK JOMBANG
}

\author{
MOCH. SYA'RONI HASAN \\ STIT al-Urwatul Wutsqo Jombang \\ roni_stit@yahoo.co.id
}

\begin{abstract}
This study describe the implementation of Management development educators at SMA Primaganda, Bulurejo Diwek, Jombang. The approach in this study is a qualitative case study type. used data collection methods as well as the role of observation, interview and documentation. This study used a qualitative descriptive approach. To check the validity of the data used extension study, perseverance observation, and triangulation. The analysis comes up with the conclusion that: (1). Development Planning educators: announcement held at the beginning of the new academic year, the drafting team was formed educators development commission held hearings, the commission meeting is a forum for reviewing, memproduct and developed the concept of the development of educators who have been prepared. (2). The development of educators with activities of interaction with educators through formal and informal activities. Formal activities in the development of educators, for example through mentoring activities (tutorials), informally can be done through informal conversations in the room as educators, yard madrassas and other places that are not resmi. (3). Problems encountered and solutions in the implementation of management efforts pengembanagan educators (teachers) at SMA Primaganda include issues of time and also there are many teachers who have not been able to use electronic means of computer, the solution given is the clock supplied to the teacher to be able to learn who helped by tutors.
\end{abstract}

Abstrak

Penelitian ini mendiskripsikan tentang pelaksanaan manajemen pengembangan pendidik (educators) di SMA Primagama, Bulurejo Diwek, Jombang. Pendekatan dalam penelitian ini adalah kualitatif dengan tipe penelitian studi kasus. Metode pengumpulan data yang digunakan dalam penelitian ini adalah observasi, wawancara dan dokumentasi. Penelitian ini menggunakan pendekatan deskriptif kualitatif. Untuk mengecek validitas data, peneliti menggunakan studi ekstensi, observasi ketekunan, dan triangulasi. Berdasarkan analisis data, penelitian ini menyimpulkan bahwa: (1). Perencanaan pengembangan pendidik: pengumuman diadakan pada awal tahun ajaran baru, tim perumus membentuk komisi pengembangan pendidik untuk melakukan rapat komisi, sidang komisi adalah forum untuk mengkaji, menghasilkan dan mengembangkan konsep pengembangan pendidik yang telah disiapkan. (2). Pengembangan pendidik dilakukan dengan kegiatan interaksi melalui kegiatan formal dan informal. kegiatan formal dalam pengembangan pendidik, misalnya 
melalui kegiatan mentoring (tutorial), untuk kegiatan informal dilakukan melalui percakapan informal di ruang guru, halaman madrasah dan tempat-tempat lain yang tidak resmi. (3). Problematika dalam pelaksanaan manajemen pengembanagan pendidik (guru) di SMA Primaganda mencakup masalah waktu dan juga banyaknya guru yang belum mampu menggunakan media komputer dalam pembelajaran. Solusi dari problematika tersebut adalah memberikan waktu kepada guru untuk mempelajari media komputer yang dibantu oleh tutor.

\section{Kata Kunci: Manajemen, Pegembangan Pendidik.}

\section{Pendahuluan}

Keberhasilan sebuah bangsa dalam melaksanakan pembangunan, dipengaruhi oleh sumber daya manusia yang berkualitas. Persoalan kualitas sumber daya manusia, terutama di indonesia menjadi persoalan yang penting yang mendesak untuk dicarikan sebagai alternatif pemecahanya. Ini semua dilakukan demi tercapainya tujuan pendidikan nasional yaitu untuk mengembangkan potensi peserta didik agar menjadi manusia yang beriman dan bertaqwa kepada tuhan yang Maha Esa, berakhlak mulia, sehat, berilmu, cakap, kreatif, mandiri, dan menjadi warga negara yang demokratis serta bertanggung jawab. ${ }^{1}$

Syamsul Hadi dan Masharyono menyatakan bahwa sumber daya manusia adalah faktor sentral sebuah bangsa. Maka, apapun bentuk dan tujuanya, bangsa dibuat berdasarkan berbagai visi untuk kepentingan manusia pula. Jadi, manusia merupakan faktor strategis dalam semua kegiatan institusi/bangsa. ${ }^{2}$

Unsur sumber daya manusia mempunyai peranan yang sangat penting terhadap maju dan mundurnya suatu organisasi. Dalam hal ini Hadari Nawawi menegaskan bahwa manusia merupakan faktor sentral yang menentukan keberhasilan dan kegagalan setiap perusahaan dalam menjalankan bisnis. Manusia adalah subjek dan bukan objek dalam menjalankan pekerjaan, yang dalam hubungan kerja harus saling memperlakukan satu dengan yang lain secara manusiawi. Hubungan kerja yang paling intensif di lingkungan organisasi adalah antara pemilik (owner) dan pembantu utamanya yang diberi wewenang mengelola kegiatan organisasinya (para eksekutif/manajer) dengan para pekerja di lingkungannya. ${ }^{3}$

Jadi logika yang dapat ditarik dari statemen Hadari di atas tentang konsep MSDM jika dikorelasikan dengan pendidikan adalah bahwa sejauh manakah peranan manusia (Kepala Sekolah, guru, karyawan dan para pekerja pendidikan

\footnotetext{
1 Undang-undang Nomor 20 tahun 2003 tentang Sistem Pendidikan Nasional.

2 Buchari Alma dan Ratih Hurriati. Manajemen Corporate dan Strategi Pemasaran jasa Pendidikan, (Bandung: Alfabeta, 2008), 335.

${ }^{3}$ Hadari Nawawi, Manajemen Sumber Daya Manusia untuk Bisnis Yang Kompetitif,(Yogyakarta: Gajah Mada University Press, 2001), 7.
} 
lainnya) terhadap sukses dan gagalnya pendidikan di madrasah. Sudahkah para manajer pendidikan memperlakukan para tenaga kependidikan secara manusiawi. Kemudian bagaimana pola hubungan kerja antara kepala madrasah, pemilik yayasan, guru dan masyarakat yang sangat berpengaruh terhadap keberhasilan pendidikan madrasah. Dengan lain kata dapat dikatakan bahwa pendidikan tidak akan menjadi maju dan berkembang jika tidak diawali dengan pengembangan dan pembangunan dan pengembangan SDM secara baik dan teratur.

Berpijak dari konsep Hadari tentang MSDM di atas, maka diharapkan pendidikan Islam yang diselenggarakan oleh madrasah yang selama ini terkesan stagnan dan kurang berkualitas dapat dicarikan dan ditemukan solusi alternatif guna perbaikan dan pengembangan lembaga tersebut.

Salah satu upaya yang dapat ditempuh adalah melalui Manajemen Sumber Daya Manusia. Ini merupakan alternatif strategis untuk meningkatkan kualitas pendidikan madrasah. Dalam hal ini Mastuhu menegaskan bahwa banyak kelemahan-kelemahan yang ada dalam pendidikan Islam saat ini yang perlu diatasi. Salah satu kelemahan yang paling krusial bagi madrasah adalah manajemen yang sangat sederhana baik itu mengenai manajemen SDM, kurikulum, dan komponen-komponen pendidikan lainnya sehingga pendidikan kadang tidak direncanakan dengan baik. ${ }^{4}$

Upaya pengembangan madrasah melalui peningkatan Manajemen Sumber Daya Manusia, mendesak untuk segera dilaksanakan. Sebab bila SDM dapat dikelola dengan baik maka segala potensi yang dimilikinya dapat didayagunakan dengan semaksimal mungkin sehingga akan lahir out put pendidikan madrasah yang bermutu dan berkualitas.

Di bawah kepemimpinan Dra. Hj. Chumaidah, Syc. MPd.I. Sekolah Menengah Atas Primaganda dijadikan sebagai lembaga pendidikan Islam yang tidak hanya menjadi satuan pendidikan yang unggul dalam menghasilkan peserta didik yang berkualitas, tetapi juga mampu memberikan semangat dan motivasi yang tinggi kepada para tenaga pendidik. Salah satu bentuk penjaminan mutu pendidikan yang dilakukan oleh Sekolah Menengah Atas Primaganda adalah dengan cara terus menerus melakukan pengembangan kualifikasi dan kompetensi para tenaga pendidiknya.

Berdasarkan pada latar belakang diatas maka peneliti melakukan penelitian dengan judul manajemen pengembanagan tenaga pendidik di SMA Primaganda Bulurejo Diwek Jombang.

Penelitian ini mengambil setting di SMA Primaganda Bulurejo Diwek Jombang dengan alasan, pondok pesantren ini memiliki sistem pendidikan yang sudah cukup mapan, sistem pendidikan yang digunakan berbasis tasawuf atau thoriqoh. Selain itu juga menerapkan pendidikan gratis untuk semua siswanya yang tidak mampu.. Dari uraian di atas kemudian muncullah pertanyaan:

4 Mastuhu, "Madrasah Menggugat; Realitas Pendidikan Asli Indonesia", Edukasi, XXII, TH.VIII, September 2000, 16. 
Bagaimana perencanaan pengembangan tenaga pendidik di Sekolah Menengah Atas Primaganda Jombang? Bagaimana pelaksanaan pengembangan tenaga pendidik di Sekolah Menengah Atas Primaganda Jombang? Apa probelematika yang dihadapi dalam pelaksanaan pengembangan tenaga pendidik di Sekolah Menengah Atas Primaganda Jombang?

Pendekatan dalam penelitian ini adalah kualitatif yang berjenis studi kasus. Dalam pengumpulan data digunakan metode observasi peran serta, wawancara mendalam dan dokumentasi. Sumber data penelitian ini adalah katakata dan tindakan dari subjek penelitian yang meliputi Kepala Madrasah, dewan guru, staf TU dan siswa. Penelitian ini menggunakan pendekatan kualitatif deskriptif. Teknik analisis datanya menggunakan model analisis interaktif yang mencakup beberapa komponen yang saling berkaitan yaitu pengumpulan data, reduksi data, penyajian data dan penarikan kesimpulan. Untuk pengecekan keabsahan data digunakan perpanjangan penelitian, ketekunan pengamatan, dan triangulasi.

Manajemen adalah sebuah proses yang khas terdiri dari perencanaan, pengorganisasian, penggerakan dan pengawasan serta evaluasi yang dilakukan pihak pengelola organisasi untuk mencapai tujuan bersama dengan memberdayakan sumber daya manusia dan sumber daya lainya.istilah manajemen sering dipakai dalam dunia bisnis. Selain itu, digunakan pula untuk menjelaskan semua tipe kegiatan yang dikerjakan secara terorganisir. Dalam praktiknya, manajemen dibutuhkan dimana saja orang bekerja bersama (organisasi) untuk mencapai tujuan bersama. ${ }^{6}$ Tidak ada satupun organisasi yang tetap stabil dan tidak mengalami medifikasi untuk jangka waktu tertentu. Semuanya mengalami perubahan. Oleh karena itu, perubahan merupakan keniscayan yang dilalui dengan jalan bertukar informasi, menyerap sumberdaya yang ada dan menyediakan modal untuk mengembangkan satuan pendidikan. ${ }^{7}$ hal seperti itulah yang menyebabkan profesionalisme para tenaga pendidik terus meningkat, bahkan mampu melampui standar nasional pendidikan.

Dalam buku The dictionary of management dijelaskan bahwa manajemen adalah: "activities concerned with applying rules, procedures and policies determined by others" 8 artinya adalah aktivitas yang berhubungan dengan penerapan aturanaturan, posedur dan penentuan kebijakan oleh orang lain. Jadi manajemen adalah keseluruhan proses dengan mana sumber-sumber manusia dan materiil yang cocok dibuat tersedia dan efektif bagi pencapaian maksud-maksud organisasi secara efisien ini dijalankan melalui upaya bersama dari orang-orang. ${ }^{9}$

Secara rinci pengertian manajemen dapat disimpulkan sebagai berikut:

a. Sebagai suatu sistem, manajemen adalah suatu kerangka kerja yang terdiri dari

\footnotetext{
${ }^{5}$ Mulyono, Manajemen administrasi dan organisasi Pendidikan, (Yogyakarta: Ar ruzz), 18.

${ }^{6}$ Mulyono, Manajemen administrasi dan organisasi Pendidikan, (Yogyakarta: Ar ruzz), 3.

7Winardi, Manajemen Perilaku Organisasi, (Jakarta: kencana, 2007), 58.

${ }^{8}$ Herek French dan Heather Saward,The Dictionary of Management, (London: Paris Book, 1983), 9.

9 Ngalim Purwanto, Administrasi dan Supervisi Pendidikan, (Bandung: Remaja Rosdakarya, 2003), 1.
} 
berbagai komponen yang secara keseluruhan saling berkaitan dan terorganisis dalam rangka mencapai tujuan

b. Sebagai proses, manajemen adalah serangkaian tahap kegiatan yang diarahkan pada pencapaian tujuan dengan memanfaatkan sumber daya semaksimal mungkin

c. Sebagai suatu ilmu pengetahuan, manajemen adalah suatu ilmu interdisipliner dengan menggunakan bantuan ilmu sosial, filsafat, psikologi, antropologi dan sebagainya

d. Sebagai suatu profesi, manajemen merupakan bidang pekerjaan atau keahlian tertentu yang dapat disejajarkan dengan bidang kedokteran, hukum dan sebagainya

e. Sebagai suatu fungsi, manajemen adalah proses fungsi perencanaan, pengorganisasian, penggerakan dan pengawasan.

\section{Tujuan dan Fungsi-Fungsi Fundamental Manajemen}

Tujuan utama dari manajemen adalah untuk meningkatkan kontribusi sumber daya manusia terhadap organisasi dalam rangka mencapai produktivitas organisasi yang bersangkutan. Hal ini dapat dipahami bahwa semua kegiatan organisasi dalam mencapai misi dan tujuannya adalah sangat tergantung kepada manusia yang mengelola organisasi itu. ${ }^{10}$

Manajemen bukanlah suatu tujuan dan akhir suatu proses, melainkan suatu perangkat atau alat untuk membantu tercapainya suatu tujuan organisasi secara keseluruhan. Oleh karena itu suatu unit atau bagian manajemen di suatu organisasi diadakan untuk melayani bagian-bagian lain organisasi tersebut.

Fugsi fundamental manajamene meliputi Perencanaan (Planning) adalah proses manajemen dalam menentukkan pergerakan sumber daya manusia organisasi dari posisinya saat ini menuju posisi yang dinginkan di masa depan. Dari konsep tersebut, perencanaan sumber daya manusia dipandang sebagai proses linear, dengan menggunakan data dan proses masa lalu (short-term) sebagai pedoman perencanaan di masa depan (long-term). ${ }^{11}$

Rencana merupakan landasan bagi setiap jenis aktivitas organisasi. Perencanaan adalah proses untuk memutuskan tujuan-tujuan apa yang akan dikejar selama periode waktu mendatang dan apa yang akan dilakukan agar mencapai tujuan tersebut. Perencanaan haruslah mendahului semua aktifitas manajemen agar organisasi sukses dalam mencapai tujuannya.

Pengorganisasian (Organizing) mempunyai dua pengertian umum. Pertama organisasi diartikan sebagai suatu lembaga atau kelompok fungsional, misalnya sebuah sekolah, sebuah perkumpulan, badan- badan pemerintahan dan lain sebagainya. Kedua, merujuk pada proses pengorganisasian yaitu bagaimana pekerjaan diatur dan dialokasikan di antara para anggota, sehingga tujuan

\footnotetext{
10 Soekidjo Notoatmojo, Pengembangan Sumber Daya Manusia, (Jakarta: PT. Rineka Cipta, 1998), 110.

11 Jeffrey Pfeffer, et.al, Paradigma Baru Manajemen Sumber Daya Manusia, (Yogyakarta: Amara Books, 2003), 53.
} 
organisasi itu dapat tercapai secara efektif. Sedangkan organisasi itu sendiri diartikan sebagai kumpulan orang dengan sistem kerjasama untuk mencapai tujuan bersama. Dalam system kerjasama secara jelas diatur siapa menjalankan apa, siapa bertanggung jawab atas siapa, arus komunikasi dan memfokuskan sumber daya pada tujuan. Karakteristik sistem kerjasama dapat dilihat, antara lain 1) Ada komunikasi antara orang yang bekerjasama; 2) Individu dalam organisasi tersebut mempunyai kemampuan untuk bekerjasama; 3) Kerjasama itu ditujukan untuk mencapai tujuan. ${ }^{12}$

Pelaksanaan (actuating) merupakan fungsi yang paling fundamental dalam manajemen, karena merupakan pengupayaan berbagai jenis tindakan itu sendiri, agar semua anggota kelompok mulai dari tingkat teratas sampai terbawah, berusaha mencapai sasaran organisasi sesuai rencana yang telah ditetapkan semula, dengan cara terbaik dan benar. ${ }^{13}$

Dari penjelasan tersebut di atas, dapat dipahami bahwa yang dimaksud dengan pelaksanaan (actuating) adalah usaha untuk menggerakan anggotaanggota kelompok sedemikian rupa sehingga mereka berkeinginan dan berusaha untuk mencapai sasaran-sasaran (tujuan) organisasi tersebut karena para anggota itu ingin mencapai sasaran-sasaran tersebut ${ }^{14}$

Pengawasan (controlling) dapat dianggap sebagai aktivitas untuk menemukan, mengoreksi penyimpangan-penyimpangan penting dalam hasil yang dicapai dari aktivitas-aktivitas yang direncanakan. Adalah wajar jika terjadi kekeliruan-kekeliruan tertentu, kegagalan-kegagalan dan petunjuk-petunjuk yang tidak efektif hingga terjadi penyimpangan yang tidak diinginkan daripada tujuan yang ingin dicapai. Pengawasan dalam arti manajemen yang diformalkan tidak akan eksis tanpa adanya perencanaan, pengorganisasian dan penggerakan sebelumnya. Pengawasan tidak dapat terjadi dalam sebuah vakum. Ia merupakan bagian daripada out put ketiga macam fungsi fundamental manjemen lainnya. Makin dekat kaitan tersebut makin efektif pengawasan

\section{Manajemen pengembangan Tenaga Pendidik (Guru)}

Penggunaan ilmu manajemen dalam pengembanang tenaga pendidik dilakukan sebagai upaya dari inovasi administrasi yang didesain untuk mengembangkan keefektifan sekolah/madrasah dalam memberikan pelayanan pendidikan kepada stakeholder pendidikan. ${ }^{15}$

Development atau pengembangan, dimaksudkan untuk penigkatan mutu pegawai baik dilakukan dengan melalui pendidikan maupun kesempatankesempatan lain seperti penataran, diskusi ilmiah, lokakarya, membaca majalah

\footnotetext{
12 Nanang Fattah, Landasan Manajemen Pendidikan. (Bandung: Remaja Rosdakarya 2004), 71.

${ }^{13}$ Inu Kencana Syafi' i, Al-Qur'an dan Ilmu Administrasi, (Jakarta: Rineka Cipta, 2000), 67.

${ }_{14}$ George R. Terry, Principles of Management, terj. Winardi, Azas-Azas Manajemen, (Bandung: Alumni, 1986), 313.

15 Teguh Prasetyo, Praktik Sumber Daya Manusia yang Progresif, Upaya membangun keunggulan bersaing, Jurnal Ekonomi dan Manajmen, Vol 1 Nomor 1, (Malang: Program Maggister Manajemen Universitas Gajayana, 2000), 59.
} 
dan surat kabar, menjadi anggota organisasi profesi dan lain sebagainya. Mengatur kenaikan pangkat dan kenaikan gaji, dapat dikategorikan sebagai pemberian kesejahteraan dan dapat dikategorikan sebagai pengembangan pegawai. Pegawai yang diberi penghargaan dengan atau pemberian kedudukan, akan mendorong pegawai tersebut untuk lebih meningkatkan tanggung jawabnya.

Prinsip-prinsip Pengembangan tenaga pendidik

Prinsip yang patut diperhatikan dalam penyelenggaraan pengembangan tenaga kependidikan, yaitu:

a. Dilakukan untuk semua jenis tenaga kependidikan baik untuk tenaga stuktural, tenaga fungsional maupun tenaga teknis penyelengara pendidikan.

b. Berorientasi pada perubahan tingkah laku dalam rangka peningkatan kemampuan profesional dan atau teknis untuk pelaksanaan tugas seharihari sesuai dengan posisinya masing-masing.

c. Mendorong peningkatan kontribusi setiap individu terhadap organisasi pendidikan tau sistem sekolah; dan menyediakan bentuk-bentuk penghargaan, kesejateraan dan insentif sebagai imbalan guna menjamin terpenuhinya secara optimal kebutuhan sosial ekonomis maupun kebutuhan sosial-psikologi.

d. Mendidik dan melatih seseorang sebelum maupun sesudah menduduki jabatan/posisi.

e. Dirancang untuk memenuhi tuntutan pertumbuhan dalam jabatan, pengembangan profesi, pemecahan masalah, kegiatan remidial, pemeliharaan motivasi kerja dan ketahanan organisasi pendidikan.

\section{Proses Pengembangan Tenaga Pendidik (Guru)}

Menurut Hartati Sukirman ditinjau dari sudut manajemen secara umum, proses pembinaan dan pengembangan meliputi beberapa langkah yaitu:

a. Menganalisis kebutuhan

Analisis kebutuhan dilakukan dengan cara mengidentifikasi ketrampilan kinerja, menyusun program-program yang sesuai, melaksanakan riset, dan meningkatkan kinerja.

b. Menyusun rancangan intruksional Rancangan intruksional meliputi sasaran, metode intruksional, media, urutan dan gambaran mengenai materi pelatihan, yang merupakan kurikulum bagi program pelatihan tersebut.

c. Mengesahkan program latihan

Suatu program pelatihan harus memperoleh pertimbangan dan persetujuan dari unsur instansi yang berwenang.

d. Tahap implementasi

Tahap ini merupakan tahap pelaksanaan program pelatihan yang menggunakan berbagai teknik pelatihan misalnya diskusi, loka karya, dan seminar, dalam rangka penyampaian pengetahuan kepada para peserta program pelatihan. 
e. Tahap evaluasi dan tindak lanjut

Pada tahap ini program pelatihan dinilai sejauhmana keberhasilannya atau kegagalannya. Aspek yang perlu dievaluasi misalnya kemampuan dan hasil belajar, reaksi peserta terhadap program pelatihan, dan perilaku kinerja setelah mengikuti program pelatihan.

Dalam hal pengembangan pegawai, banyak cara yang sudah dikembangkan. pengembangan ini dilaksanakan bentuk (1) Bimbingan berupa petunjuk yang diberikan kepada pegawai, pada waktu melaksanakan tugasnya; (2) Latihanlatihan berupa intern dan ekstern; (3) Pendidikan formal; (4) Promosi berupa pengangkatan jabatan ke yang lebih tinggi; (5) Penataran dan Lokakarya atau workshop.

Cara yang lebih populer adalah melalui penataran (inservice training) baik dalam rangka penyegaran maupun dalam rangka peningkatan kemampuan tenaga kependidikan. Cara-cara lainnya dapat dilakukan sendiri-sendiri (self propelling growth) atau bersama-sama (collaborative effort), misalnya mengikuti kegiatan atau kesempatan; ore-service training, on the job training, seminar, workshop, diskusi panel, rapat-rapat, simposium, konferensi dan sebagainya.

\section{Metode Penelitian}

Berdasarkan analisis dan taraf pembahasan, penelitian ini berjenis kualitatif yang bertujuan untuk memahami (understanding) dunia makna yang disimpulkan dalam perilaku masyarakat (guru) menurut perspektif masyarakat (lingkungan sekolah) itu sendiri16, karena bersifat understanding, maka pelaporannya bersifat diskriptif dan naratif ${ }^{17}$.

Instrumen pengumpulan data yang dipakai pada penelitian ini adalah observasi, wawancara, dan dokumentasi. Observasi penulis gunakan sebagai instrumen untuk memperoleh data utama (primer). Observasi yang penulis lakukan yaitu observasi partisipatif secara terbuka. Observasi dilakukan untuk mengamati proses manajemen pengembanagan tenaga pendidik di SMA Primaganda Bulurejo Diwek Jombang.

Pola interview yang digunakan ialah wawancara bebas terpimpin, yakni sebelumnya telah dibuat draf atau panduan interview yang berfungsi sebagai pengarah agar interview tetap efektif dan efisien. Selain itu agar penulis mempunyai arsip dokumen dari data yang diperoleh dari responden. Sasaran interview dalam penelitian ini adalah kepala sekolah dan guru dilingkungan sekolah tersebut.

Dokumentasi menurut penulis adalah instrumen pendukung utama yang sangat valid, karena dokumentasi dapat dijadikan bukti akurat. Dokumentasi dalam penelitian ini digunakan untuk memperoleh data pendukung (sekunder)

${ }^{16}$ Basrowi dan Sukidin, Metode Penelitian Kualitatif Perspektif Mikro, (Surabaya: Insan Cendikia, 2002), 2.

${ }^{17}$ Imam Suparyogo dan Tobroni, Metodologi Penelitian Sosial Agama, (Bandung: Remaja Rosdakarya, 2001), 8. 
tentang identitas sekolah, identitas guru dan lain-lain yang berhubungan dengan proses manajemen pengembanagan tenaga pendidik di SMA Primaganda Bulurejo Diwek Jombang.

Jenis penelitian ini adalah penelitian kualitatif. Karena jenis penelitian kualitatif, menurut Miles dan Huberman, analisis datanya menggunakan analisis data kualitatif, yaitu melakukan analisis secara interaktif dan berlangsung secara terus menerus sampai tuntas hingga datanya sudah mencapai taraf "redundanct" atau "jenuh". Aktivitas analisis data tersebut, meliputi data reduction, data display, dan data conclusion drawing/verifikation ${ }^{18}$.

\section{Hasil Penelitian dan Pembahasan}

\section{Perencanaan Pengembangan Tenaga Pendidik di SMA Primaganda}

Perencanaan pengembanagn tenaga pendidik merupakan salah satu kegiatan manajerial terpenting dalam menciptakan sumber daya manusia berkualitas di setiap lembaga pendidikan Islam. Hal ini penting sebab tanpa adanya penyusunan perencanaan pengembangan tenaga pendidik, maka arah pengembangan tenaga pendidik di lembaga pendidikan menjadi tidak menentu. Menurut Fatah, perencanaan merupakan proses penentuan tujuan atau sasaran lembaga pendidikan Islam yang hendak dicapai. Selain itu, juga sebagai penetapan jalan dan sumber yang diperlukan untuk mencapai tujuan lembaga pendidikan Islam seefisien dan seefektif mungkin. ${ }^{19}$

Perencanaan pengembangan kompetensi yang melibatkan ide dari seluruh tenaga pendidik dalam sidang komisi yang dilaksanakan pada awal tahun pelajaran baru, merepresentasikan pengembangan tenaga pendidik di Sekolah Menengah Atas Primaganda didasari nilai-nilai demokratis dan penuh nuansa keadilan serta komitmen untuk melaksanakannya secara terus menerus.

Keberadaan kegiatan pengembangan tenaga pendidik di SMA Primaganda, menjadikan tenaga pendidik terus terkondisikan untuk meningkatkan profesionalismenya. Situasi yang demikian, akan memicu peningkatan kompetensi tenaga pendidik SMA Primaganda. Dalam kondisi tersebut, paradigma (insight) pentingnya profesionalisme akan sedikit demi sedikit terbentuk dalam pola pikir maupun pola sikap tenaga pendidik SMA Primaganda.

Kepala sekolah memainkan peranan penting dalam memutuskan perencanaan pengembangan tenaga pendidik yang terbaik. Untuk memainkan peranan tersebut, Chumaidah sebagai salah seorang pimpinan (top manager) di lembaga pendidikan Islam, mengimplementasikan pendekatan manajerial dengan cara menggunakan berbagai sumber daya manusia yang tersedia di SMA

${ }^{18}$ Harun Rasyid, Metode Penelitian Kualitatif Bidang Ilmu Sosial dan Agama, (Pontianak: STAIN Pontianak, 2000), 123; Suparyogo dan Tobroni, Metode Penelitian Kuantitatif Kualitatif dan RED, (Bandung: Alfabeta, 2001), 193; dan Sugiyono, Metode Penelitian Kuantitatif Kualitatif dan RED, (Bandung: Alfabeta, 2007), 246.

${ }^{19}$ Nanang Fatah, Landasan Manajemen Pendidikan, (Bandung: Remaja Rosdakarya, 2004), 2004. 
Primaganda. Sebagian besar kebijakan dalam perencanaan pengembangan tenaga pendidik dilakukan dengan cara partisipatoris. Perlibatan tenaga pendidik yang terdaftar di SMA Primaganda merupakan bukti adanya penyusunan perencanaan pengembangan tenaga pendidik dilakukan secara pertisipatoris.

Komitmen untuk mengembangkan kompetensi di dalam kalangan tenaga pendidik SMA Primaganda akan terus meningkat, bila tenaga pendidik tersebut merasa dipercaya, mendapat penghargaan dari hasil kerjanya, meras mendapatkan keadilan di tempat kerja dan mendapatkan tantangan untuk menunjukkan kemampuannya. ${ }^{20} \mathrm{Hal}$ ini, merupakan salah satu cara memberikan kepercayaan, sekaligus tantangan kepada tenaga pendidik SMA Primaganda untuk menunjukkan kemampuannya dalam meningkatkan profesionalisme. Pendekatan psikologis yang dilakukan pengelola SMA Primaganda mampu meningkatkan komitmen tenaga pendidik tersebut dalam meningkatkan mutu pembelajaran di lembaga pendidikan Islam tersebut. ${ }^{21}$

Kepala SMA Primaganda Drs.Hj.Chumaidah Syc,M.Pd memberdayakan seluruh komponen madrasah untuk membuka ide, menyusun gagasan dan menetapkan sebagai keputusan yang berkaitan dengan program pengembangan tenaga pendidik. Situasi tersebut, menimbulkan antusiasme yang diiringi konsistensi dalam implementasi oleh tenaga pendidik SMA Primaganda. Proses tersebut tergambar dari mekanisme sidang komisi yang diselenggarakan pada seetiap akan dimulainya tahun ajaran baru. Hal ini juga memperlihatkan bahwa sistem manajerial dalam segi perencanaan, di SMA Primaganda telah dijalankan sesuai dengan Peraturan Menteri Pendidikan Nasional Nomor 19 Tahun 2007 tentang Standar Pengelolaan Pendidikan yang menyatakan rencana kerja tahunan yang dijadikan dasar pengelolaan sekolah/ madrasah dilaksanakn dengan prinsip kemandirian, kemitraan, pertisipasi, keterbukaan dan akuntabilitas serta memuat ketentuan yang jelas mengenai tenaga pendidik dan tenaga kependidikan serta pengembangannya. Maka dari itu, pengembangan tenaga pendidik menjadi bagian penting dalam sistem manajemen SMA Primaganda dalam mewujudkan lembaga pendidikan Islam tersebut menjadi bertaraf internasional.

Dengan dipenuhinya hal tenaga pendidik menjadikan tenaga pendidik di SMA Primaganda merasa mendapatkan banyak manfaat dalam program pengembangan peningkatan kompetensi terutama dalam segi teknologi informasi dan komunikasi. SMA Primaganda mempunyai kebijakan yang tidak mempersulit bahkan memfasilitasi tenaga pendidik yang berinisiatif mengikuti kegiatan pengembangan tenaga pendidik yang diselenggarakan di dalam maupun di luar lembaga pendidikan Islam tersebut. Hal inilah yang menyebabkan proses peningkatan profesionalisme tenaga pendidik di SMA Primaganda terus berlangsung. Berdasarkan temuan hasil penelitian tentang perencanaan pengembangan tenaga pendidik di SMA Primaganda, maka dapat digambarkan

\footnotetext{
20 Direktorat Pembinaan TK dan SD Kemendiknas, Panduan Penyelenggaraan Sekolah Dasar Standar Nasional, (Jakarta: kemendiknas, 2008), 9.

${ }^{21}$ Direktorat Pembinaan TK dan SD Kemendiknas, panduan Penyelenggaraan..., 9.
} 
dalam penjelasan Burnham dalam teori kerja tim yang efektif sebagaimana berikut:

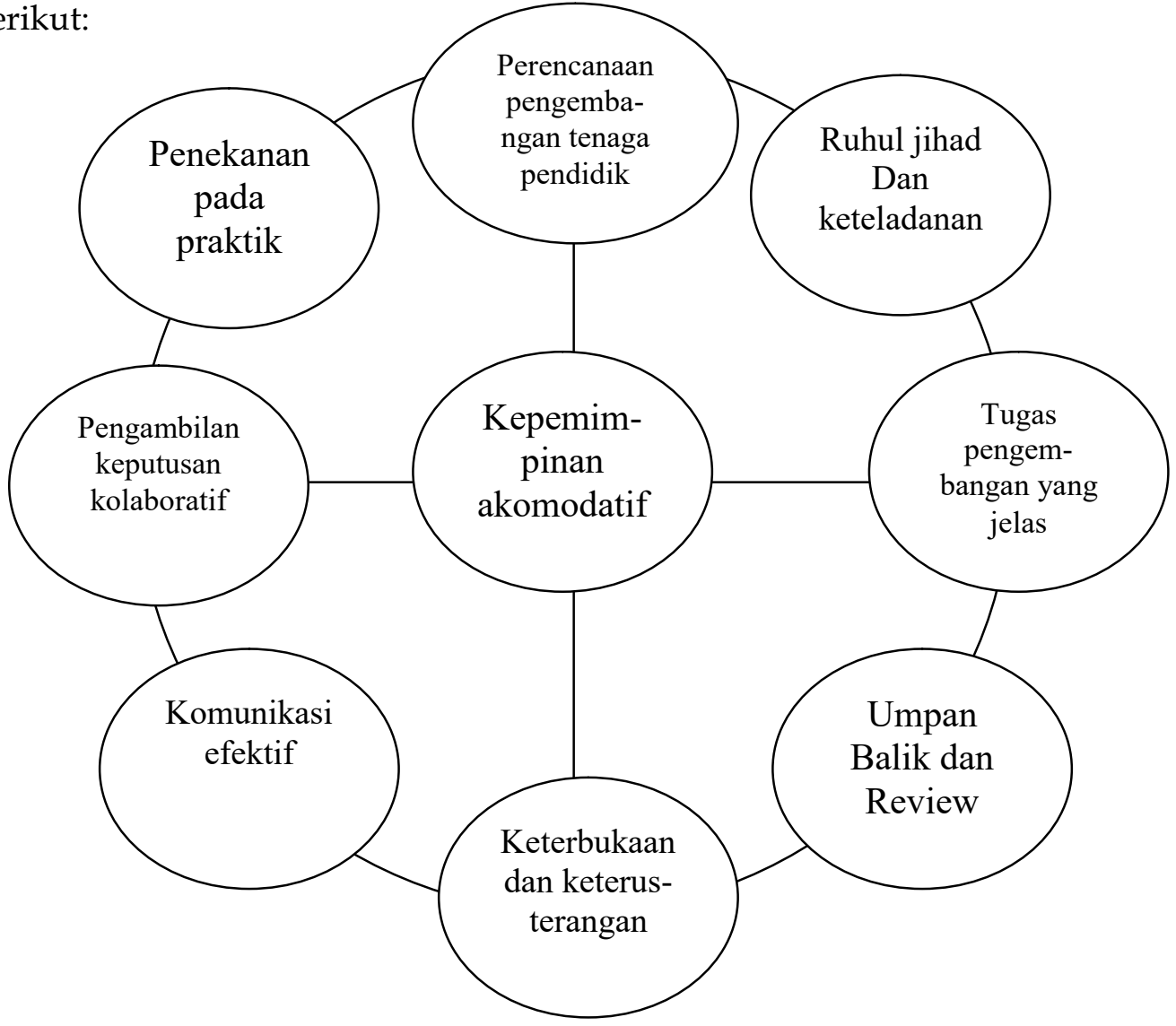

\section{Gambar}

\section{Proses Perncanaan Pengembangan Tenaga Pendidik yang Efektif}

Gambar tersebut menjelaskan bahwa perencanaan pengembangan tenaga pendidik tim yang efektif memiliki persepsi dan nilai-nilai kebersamaan yang dimiliki oleh semua tenaga pendidik. Adanya kesamaan dan konsistensi dalam perencanaan pengembangan tenaga pendidik berdampak terhadap berbagai hal, misalnya adanya kesadaran untuk meningkatkan kemampuan profesional tenaga pendidik. Nilai-nilai inilah yang menjadikan proses perencanaan pengembangan tenaga pendidik tidak mengalami resistensi (penolakan) yang berlebihan baik kepada tenaga pendidik junior maupun senior. Adanya model perencanaan yang demikian juga membuat iklim akademik di SMA Primaganda juga semakin kondusif.

\section{Analisa Pelaksanaan Pengembangan Tenaga Pendidik di SMA Primaganda}

Pelaksanaan pengembangan tenaga pendidik di Sekolah Menengah Atas Primaganda tergambar dari kegiatan belajar mengajar yang sedang berlangsung. Hal ini terlihat dari upaya SMA Primaganda Memaksimalkan 
penggunaan teknologi informasi dan komunikasi sebagai perangkat pembelajaran.

Sekolah menengah Atas Primaganda terkait dengan pengembanagan tenaga pendidik antara lain sebagai berikut: pertama, pihak lembaga pendidikan di tuntut membuat daftar urut prioritas tenaga pendidik, tenaga teknis dan tenaga tata laksana untuk mengikuti tata penataran/pelatihan seperti kelompok Kerja Guru dan Musyawarah Guru Mata Pelajaran. Kedua, melakukan pembinaan secara teratur terhadap tenaga pendidik, tenaga teknis dan tenaga tata laksana dalam melaksanakan tugas sehari-hari. Ketiga, berlangganan majalah/koran pendidikan yang berisi peningkatan profesi untuk tenaga pendidik, tenaga teknis dan tenaga tata laksana. Keempat, memberikan dorongan terhadap tenaga pendidik, tenaga teknis dan tenaga tata laksana untuk menambah pengetahuan.

Dengan demikian, proses pelaksanaan pengembangan tenaga pendidik SMA Primaganda mempunyai kesesuaian dengan teori Nemser dan Pakar yang menyatakan pengembangan tenaga pendidik dapat di lakukan dengan kegiatan interaksi dengan tenaga pendidik lainnya. Cara tersebut di lakukan melalui kegiatan formal maupun informal. Kegiatan Formal dalam pengembangan tenaga pendidik, misalnya melalui kegiatan mentoring (tutorial) yang dilakukan oleh tenaga pendidik senior terhadap tenaga pendididk baru (novice) yang belum berpengalaman berdasarkan penugasan secara secara resmi dari madrasah. Sedangkan kegiatan pengembangan tenaga pendidik secara informal dapat dilakukan melalui kegiatan pembicaraan yang tidak resmi seperti di ruang tenaga pendidik, halaman madrasah dan tempattempat lainnya yang sifatnya tidak resmi. Hal inilah, yang menurut Nemser dan Pakar sebagaimana di kutip oleh Mariani dan Doriza, dapat menjadikan tenaga pendidik di SMA Primaganda dapat menimba berbagai pengetahuan dan keterampilan dari mentornya.

2. Analisis problema yang dihadapi dan upaya pemecahannya dalam pelaksanaan manajemen pengembanagan tenaga pendidik (guru)

Suasana kerja yang kondusif dan harmonis menjadikan kegiatan pengembangan tenaga pendidik sebagai tantangan yang harus diselesaikan dan bukannya menjadi beban yang harus dihindari. Hal seperti inilah yang akan membentuk budaya organisasi di SMA Primaganda menjadi bagian penting dalam mewujudkan profesionalisme tenaga pendidik.

Adanya kesamaan nilai mengenai pentingnya pengembangan profesi tenaga pendidik menjadi landasan penting dalam mewujudkan SMA Primaganda menjadi satuan pendidikan bertaraf internasional yang tidak terjebak pada segi formalitasnya, namun juga mampu memenuhi ranah subtantif sebagaimana tertuang dalam buku "Pedoman Penjaminan Mutu Sekolah/ Madrasah Bertaraf Internasional pada Jenjang Pendidikan Dasar dan Menengah" yang diterbitkan oleh Kementerian Pendidikan Nasional. Terdapatnya suasana kerja kondusif pula juga mampu menjadikan pengembangan tenaga pendidik menjadi terlaksana dengan baik. Hal ini 
meyebabkan implikasinya dalam peningkatan mutu pembelajaran dapat ikut terasakan.

Program ini mampu meningkatkan mutu pembelajaran di SMA Primaganda terutama dalam segi penyampaian materi yang telah menggunakan teknologi informasi dan komunikasi dalam kegiatan belajar mengajar, Selain itu, juga ditemui adanya peningkatan kualitas dalam segi mental dan keberanian dalam menjadikan bahasa inggris sebagai bahasa pengantar dalam kegiatan belajar mengajar terutama bagi peserta didik yang duduk di kelas rintisan madrasah bertaraf internasional

Dalam program pengembanagan terdapat juga permasalahn yang nantinya di akan dicari solusinya. Permasalahan serta upaya dalam menyelesaikan masalah yang ada, diantaranya adalah:

Permasalahan yang terjadi pada proses pengembanagan tenaga pendidik adalah:

a) Masalah waktu yang tidak sesuai dengan rencana

Perencanaan yang ada adalah dilaksanakan satu bulan sekali akan tetapi terkadang dikarenakan tidak bisanya tutor maka tidak bisa istiqomah

b) Masih banyaknya guru-guru yang gaptek dengan alat-alat elektronik jadi program pengembanagan tidak sesuai dengan yang ditargetkan.

Permasalahan seperti ini akan ditanggulangi dengan adanya jam tambahan untuk guru-guru yang masih belum paham dan menguasai alat elektronik diantaranya bisa menggunakan tutor sebaya dan dijadwalkan setiap hari ahad

\section{Penutup.}

Setelah diadakan penelahaan pada pemaparan sebelumnya maka dapat dirumuskan simpulan sebagai berikut:

1. Perencanaan Pengembanagan tenaga pendidik di SMA Primaganda tidak terlepas dari peranan kepala sekolah dalam memutuskan perencanaan pengembangan tenaga pendidik yang terbaik Perencanaan program pengembangan tenaga pendidik, awalnya diadakan pengumuman pada awal tahun ajaran baru kepada seluruh tenaga pendidik SMA Primaganda Kemudian setelah semua tenaga pendidik mengetahui informasi tersebut, lalu dibentuklah tim penyusun pengembangan tenaga pendidik. Tim ini kemudian menyusun program pengembanagan tenaga pendidik yang melibatkan seluruh warga madrasah. Setelah kerangka penyusunan konsep pengembanagan tenaga pendidik terbentuk, maka diadakan sidang komisi, sidang komisi adalah forum untuk mereview, memproduk dan mengembangkan konsep pengembangan tenaga pendidik yang telah disusun

2. Pelaksanaan pengembangan tenaga pendidik SMA Primaganda di lakukan dengan kegiatan interaksi dengan tenaga pendidik lainnya. Cara tersebut di lakukan melalui kegiatan formal maupun informal. Kegiatan Formal dalam pengembangan tenaga pendidik, misalnya melalui kegiatan mentoring (tutorial) yang dilakukan oleh tenaga pendidik senior terhadap tenaga pendididk baru (novice) yang belum berpengalaman berdasarkan penugasan 
secara secara resmi dari madrasah. Sedangkan kegiatan pengembangan tenaga pendidik secara informal dapat dilakukan melalui kegiatan pembicaraan yang tidak resmi seperti di ruang tenaga pendidik, halaman madrasah dan tempattempat lainnya yang sifatnya tidak resmi.

3. Problema yang dihadapi dan upaya pemecahannya dalam pelaksanaan manajemen pengembanagan tenaga pendidik (guru) di Sekolah Menengah Atas Primaganda diantaranya permasalahan waktu dan juga masih banyaknya guru yang belum bisa menggunakan alat elektronik computer maka solusi yang diberikan adalah dengan disediakan jam kepada guru untuk bisa belajar yang dibantu oleh tutor.

\section{DAFTAR RUJUKAN}

Alma, Buchari dkk. Manajemen Corporate dan Strategi Pemasaran jasa Pendidikan. (Bandung: Alfabeta 2008).

Basrowi dan Sukidin, Metode Penelitian Kualitatif Perspektif Mikro, (Surabaya: Insan Cendikia, 2002)

Direktorat Pembinaan TK dan SD Kemendiknas. Panduan Penyelenggaraan Sekolah Dasar Standar Nasiona. (Jakarta: Kemendiknas. 2008).

Fatah, Nanang. Landasan Manajemen Pendidikan. (Bandung: Remaja Rosdakarya 2004).

French, Herek dkk. The Dictionary of Management. (London : Paris Book. 1983).

Mulyono. Manajemen Administrasi dan Organisasi Pendidikan. (Yogyakarta. Utama Press 2007).

Nawawi, Hadari. Manajemen Sumber Daya Manusia untuk Bisnis Yang Kompetitif, (Yogyakarta: Gajah Mada University Press. 2001).

Notoatmojo, Soekidjo. Pengembangan Sumber Daya Manusia. (Jakarta: PT. Rineka Cipta. 1998).

Pfeffer, Jeffrey et.al. Paradigma Baru Manajemen Sumber Daya Manusia, (Yogyakarta: Amara Books. 2003)

Prasetyo, Teguh. Praktik Sumber Daya Manusia Yang Progresif, Upaya Membangun Keunggulan Bersaing, Jurnal Ekonomi Dan Manajmen, Vol 1 Nomor 1. Malang: Program Maggister Manajemen Universitas Gajayana. 2000.

Purwanto, Ngalim. Administrasi dan Supervisi Pendidikan. (Bandung : Remaja 
Rosdakarya. 2003).

Rasyid, Harun, Metode Penelitian Kualitatif Bidang Ilmu Sosial dan Agama, (Pontianak: STAIN Pontianak, 2000)

Suparyogo, Imam dan Tobroni, Metodologi Penelitian Sosial Agama, (Bandung: Remaja Rosdakarya, 2001) 2001)

Metode Penelitian Kuantitatif Kualitatif dan RED, (Bandung: Alfabeta, 2001)

Sugiyono, Metode Penelitian Kuantitatif Kualitatif dan RED, (Bandung: Alfabeta, 2007)

Syafi'i, Inu Kencana. Al-Qur'an dan Ilmu Administrasi. (Jakarta: Rineka Cipta. 2000).

Terry, George R. Principles of Management, terj. (Winardi, Azas-Azas Manajemen) (Bandung: Alumni. 1986).

Undang-undang Nomor 20 tahun 2003 tentang Sistem Pendidikan Nasional

Winardi, Manajemen Perilaku Organisasi. (Jakarta: Kencana, 2008) 